\title{
REDORT from the
}

IOINT COMMISSION ON FEDERAL BASE CONVERSION THE COMMONWEALTH OF MASSACHUSETTS

3 Tremont Street, Room 640, Boston, Massachusetts $02108 \cdot(617) 727-8257$

CONSTRUCTION AND MAINTENANCE OF $\underline{\text { A }}$

BRA

LEASED FISHING BOAT FLEET AT THE

SOUTH BOSTON NAVAL ANNEX

Preliminary Report

DRAFT: FOR DISCUSSION

Attached is a report which makes a preliminary examination of factors involved in constructing a fleet of modern, series-produced fishing vessels for the North Atlantic. The purpose of this initial analysis is to assess the general concept, and to raise issues for further study.

This report was prepared by VTN Consolidated, Inc. at the request of the Joint Commission on Federal Base Conversion for its own use and for use by the Boston Economic Development and Industrial Corporation. It was financed through a grant from the New England Regional Commission.

As tentative and general as the conclusions of this report are, they seem at this point to merit further attention. The Commission and the Boston Economic Development and Industrial Corporation welcome any and all comments on the content of the report and on the concept in general.

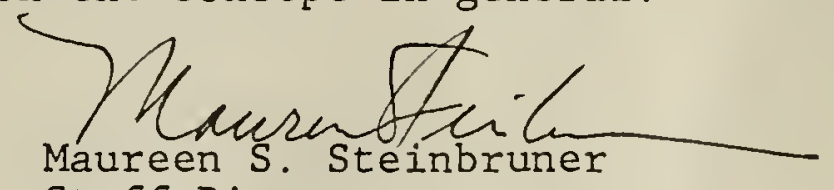
Staff Director

Publication 非8421-31-50-9-75-CR

Approved by Alfred C. Holland, State Purchasing Agent. 
Engineers Architects Planners Economists

575 Technology Square, Cambridge. Massachusetts 02139 (617) 354-1200

August 12, 1975

Ms. Maureen Steinbruner

Staff Director

Massachusetts Federal Base

Conversion Commission

73 Tremont Street

Boston, Massachusetts 02108

Dear Ms. Steinbruner:

Submitted herewith is the report on the preliminary assessment of information relating to the commission's questions as outlined in VTN letter dated June 9, 1975.

A11 facts appear to be consistent in implying that the concept for a combination construction/leasing/maintenance/repair operation for Northeast Fisheries offshore fishing vessels on the former South Boston Naval Shipyard is worthy of further consideration by the Massachusetts Federal Base Conversion Commission. Most important is the potential for a very large number of job opportunities that are associated with such a development.

We have attempted to provide the Commission with a practical assessment of the questions raised regarding the operational features and status of the existing offshore fishing vessels in the industry. We also have attempted to avoid entrapment in the historical arguments involving availability of fish stocks and foreign fishing pressures. Assessments have been made on actual United States 1976 allocations of stocks established by the International Commission for the Northwest Atlantic Fisheries (ICNAF). We hope that utilization of this type of information in the report will establish both a realistic and practical base for judgement of the concept under consideration.

Very truly yours,

VTN CONSOLIDATED, INC.

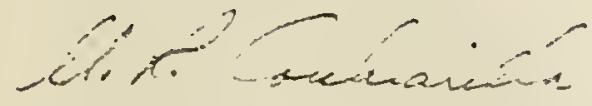

U.R. Cocchiarella

Vice President 



\section{Potential Utilization of the South Boston \\ Naval Annex for the Construction and \\ Maintenance of a Leased Fishing Boat Fleet}

FOREWORD

VTN Consolidated, Inc. has been contracted by the Massachusetts Commission on Federal Base Conversion to develop a preliminary assessment of several questions relating to the potential development of a construction/leasing/maintenance/repair operation for Northeast Offshore fishing vessels at the former South Boston Naval Shipyard. This preliminary assessment relates specifically to the following questions:

1. Given the current size of the Northeast domestic offshore fleet, and reasonable assumptions about a) production rates and b) demand, or market for the vessels, what is anticipated in terms of a target fleet size for hypothetical producer-lessor?

2. How does the estimated cost of building this vessel compare with current production costs for vessels out of New England?

Preliminary information is desired on estimated costs of building this vessel type in domestic yards for the offshore industry under current arrangements.

3. How would the operating costs of the type of vessel envisioned compare with the modal operating costs of vessels currently operating?

The type of vessel envisioned is a modern offshore trawler with an operating radius of approximately five hundred miles and not of a presently untested boat design.

4. How would the revenue form the type of vessel envisioned compare with modal revenues of vessels currently operating? 
Since the Navy first announced its intention to phase out the Charlestown Navy Yard and the South Boston Naval Annex several years ago, there have been numerous federal, state, local, and private investigations of the possibility and feasibility of converting one or both facilities to some sort of commercial venture that could provide employment, maintain, or expand the local tax base, and, necessarily, provide prospective developers with a fair profit. Though some of the proposed projects made only peripheral use of the valuable marine nature of the two properties (apartments with harbor view, for example), several of the proposals have naturally been heavily oriented towards direct marine use, especially shipbuilding. The most ambitious and visible of these, Boston Shipbuilding Corporation, appeared to have failed for reasons beyond the scope of this discussion, but unquestionably part of the reason for the failure was the severely depressed shipping market that currently prevails worldwide.

One might argue, however, that another part of the reason for its failure was its attempt to enter an already saturated market with a history of marginal profit performances nationwide. That the Boston Shipbuilding Company had the bad luck to try to come on line at this particular time was perhaps just an unfortunate coincidence, but it does seem apparent that, even in the best of times, a new American shipyard aiming at a broad spectrum medium size ship market does not have an especially exciting prognosis. The capital requirements are too great, the minimum acceptable business volume to sustain the investment is too large, and the demand function is too thin to hold much promise for this kind of enterprise.

The concept being explored here, on the other hand, has several important differences. It begins by overcoming the temptation to fully utilize the size capabilities of South Boston in establishing a product line. It is, after all, not essential to build 80,000 DWT ships simply because the dry dock is there. The dock and all of the other facilities must be viewed in terms of their marginal operating costs given the fact that they already exist. Once this psychological jump is made, it becomes possible to look at the full range of vessels that might be built in one or both of the facilities and to assess their feasibility on a more national basis. 
The concept being examined here takes cognizance of the possibility of building much smaller vessels than the yards could handle at their limits and looks to an industry rooted deep in the folklore and economics of the Boston area and one in which the potential demand for new vessels is enormous. It serves no purpose here to recite again all the dreary statistics about the New England groundfish industry and its continually decreasing performance in fish landed as a percentage of fish caught in the nearby fishing grounds. The rising catch rate for the international fleet in recent years shows that the resources are there to support a large fleet and the impending passage of a 200-mile limit indicates the potential for a rapid increase in demand for domestically built boats. The initial capital required for such boats is substantial, however, and may well be beyond the reach of many fishermen acting as individuals or families.

From these broad considerations, then, comes the concept being examined here. In brief, it is to use one or both of the former Navy properties in Boston to build and maintain a fleet of modern, well-equipped steel stern trawlers of a size and design specifically suited for the New England Offshore. Fisheries. This concept also includes, however, a unique approach to the capjtalization and operation of the vessels. Rather than purchasing the vessels outright, which current experience shows is not generally possible, the historic and traditional fishermen would lease them from a vessel owning entity. The exact nature of this entity as wi11 as the exact terms of the leases will be a matter for a full detailed study being proposed, but the general outlines of the lease terms and the owning entity seem apparent even at this point in time. The entity must be capital rich and, in all probability, would be diversified and successful enough to have current and projected profits which will permit it to take advantage of investment tax credits on the one hand and to mitigate the down side risks through pre-tax loss absorption on the other. The lease arrangements will dictate the rates, with short term leases having seasonal variations in rates and rates for longer term leases being based on the average annual earning capacity of the vessels.

Against this broad background, we can now proceed to examine fundamental questions: a) Is it technically feasible to build fishing vessels 
at Charlestown and/or South Boston; b) What size vessel is most likely to be successful? ; c) What will it cost to build such a vessel? ;

d) What annualized average leasing rate will be required to make ownership of the vessels commercialiy attractive?; and e) Can the fishermen afford to pay such a rate? 
Any discussion on the hypothetical size of the offshore fleet required to service the Northeast Fisheries necessarily involves the classic arguments concerning the availability of fish stocks in the producing areas. This eternal argument has plagued the New England Fishing Industry from the time of its inception. Recent developments of foreign fishing efforts and pressure in traditional United States producing areas have introduced a pessimistic attitude in some rishing circles. This assessment, however, must consider the impact and arguments in favor of conservation measures and the regulatory requirements for controlling foreign fleets that are operating in the areas.

The following discussion attempts to establish the approximate amount of stock presently estimated to exist that is allocated to the fishing efforts of the United States vessels in the offshore industry. Some indication of the future of these stocks and their allocation will also be discussed as part of the information established by the National ilarine Fisheries Service. All information regarding National Allocation and Allowable Catches has been obtained through the National Marine Fisheries Service.

To avoid confusion, one important fact must be established. The Target Fleet under discussion is made up only of the vessels that would be operating as part of the offshore fleet and does not include the smaller class of vessels involved in the in-shore industry. We classify the existing in-shore fleet as made up of the smaller fishing vessel of under fifty tons, even though the larger vessels on occasion operate in in-shore areas. The Target Fleet would be made up of vessels with an approximate operating range of five hundred miles. This range wouid permit the vessel to operate in areas of interest to the offshore New England Fishing industry. These areas would include primarily ICNAF Sub areas (4), (5), and (5). 


\section{UNITED STATES NATIONAL ALLOCATION}

The 25th Annual Meeting of the International Commission for the Northwest Atlantic Fisheries (ICNAF) was held at Edinburgh, Scotland, from 10-20 June 1975. Representatives attended from all Member Countries as follows: Bulgaria, Canada, Denmark, France, Federal Republic of Germany, German Democratic Republic, Iceland, Italy, Japan, Norway, Poland, Portugal, Rumania, Spain, Union of Soviet Socialist Republics, United Kingdom, and United States of America. Observers were present from Cuba, European Economic Council (EEC), Food and Agriculture Organization of the United Nations (FAO), International Commission for the Conservation of Atlantic Tunas, and the International Council for the Exploration of the Seas.

The main purpose of the meeting was to establish national quotas for 1976 for the major fish stocks in the Northwest Atlantic, and to consider improvements to existing regulations to the management of fish stocks in the Soviet Enforcement Scheme. The Commission agreed to total allowable catches (TAC's) for 1976, with three exceptions, in respect to fifty species stocks. Decisions were deferred on nine stocks (cod, haddock, redfish, American plaice) in subareas 3 and 4 to a Special Commission Meeting in September, 1975 and on herring stocks in subarea 5 to a Special Commission Meeting in January, 1976. The Commission further agreed to institute an international scientific observer program, not related to enforcement, for the purpose of obtaining more detailed information than is now available on by-catch and discards.

The possibilities of manaing fisheries by limitation of fishing effort were again discussed. The Commission agreed to certain measures which would improve the enforcement of fishing regulations and facilitate the work of inspectors in carrying out their duties. 
Species and stock area Total Allowable Catches and National Allocation for the United States agreed at the 1975 Annual Meeting of ICNAF with exception as previously noted are as follows:

Species

Stock Area

Total Allowable Catches

\begin{tabular}{ll}
\hline cod & 3 NO \\
& 3 PS \\
& 4 TVn \\
& $5 \mathrm{Y}$ \\
& $5 \mathrm{Z}$
\end{tabular}

In Metric Tons

\begin{tabular}{|c|c|c|}
\hline Haddock & $\begin{array}{l}4 x \\
5\end{array}$ & $\begin{array}{l}\text { (Deferred) } \\
4,450\end{array}$ \\
\hline Redfish & $\begin{array}{l}3 P \\
4 \mathrm{VWX} \\
5\end{array}$ & $\begin{array}{l}\text { (Deferred) } \\
\text { (Deferred) } \\
13,000\end{array}$ \\
\hline Red Hake & $\begin{array}{l}5 \mathrm{Ze} \\
5 \mathrm{Zw}+6\end{array}$ & $\begin{array}{l}1,000 \\
6,000\end{array}$ \\
\hline Silver Hake & $\begin{array}{ll}5 & Y \\
5 & \mathrm{Ze} \\
5 & \mathrm{Zwe}+6\end{array}$ & $\begin{array}{l}9,500 \\
8,500 \\
9,000\end{array}$ \\
\hline Yellowtail & $\begin{array}{l}5\left(E 69^{\circ}\right) \\
5\left(W 69^{\circ}\right)\end{array}$ & $\begin{array}{r}15,900 \\
3,990\end{array}$ \\
\hline American Plaice & 3 LNO & (Deferred) \\
\hline Flounders & $\begin{array}{l}4 \text { VWX } \\
5+6\end{array}$ & $\begin{array}{r}350 \\
19,500\end{array}$ \\
\hline Pollock & $4 V W X+5$ & 11,500 \\
\hline Mackerel & $\begin{array}{l}3+4 \\
5+6\end{array}$ & $\begin{array}{r}500 \\
4,700\end{array}$ \\
\hline Herring & $\begin{array}{l}4 X W(b) \\
5 Y \\
5 Z Z+6\end{array}$ & $\begin{array}{r}500 \\
9,000 \\
60,000\end{array}$ \\
\hline
\end{tabular}


Squid-Loligo

$5+6$

8,500

Other Finfish

$5+6$

68,000

(Except TAC Species and a Tso menhaden, billfishes, tunas, and large sharks)

Total Allowable

Catches in Metric

Tons

289,190 
The latest statistical information relating to Basic Catch of the U.S.A. in ICNAF Sub Areas (4), (5), and (6), which are the basic operating areas of the Target Fleet, refers to the fishing effort for the year 1973. Summary A has been prepared for vessels classified by tonnage from 50-500 and includes a variety of gear types associated with various fishing efforts. We believe that this summary may be taken as an approximate indication of the total of the offshore 1973 effort of the U.S. fleet in these areas. Vessels under fifty tons would primarily be involved in the in-shore industry and, as such, are not included.

SUMMARY A

Tabulation of 1973 Basin Catch of U.S. A. in ICNAF Sub Areas 4, 5, and 6 , by vessels classified by tonnage from 50-150 and 150-500. Gear include Otter Trawl Side, Otter Trawl Stern, Midwater Trawl, Midwater Trawl Side, Midwater Trawl Stern, Pair Trawl, Purse Seine, Long Line Set, and Dredge.

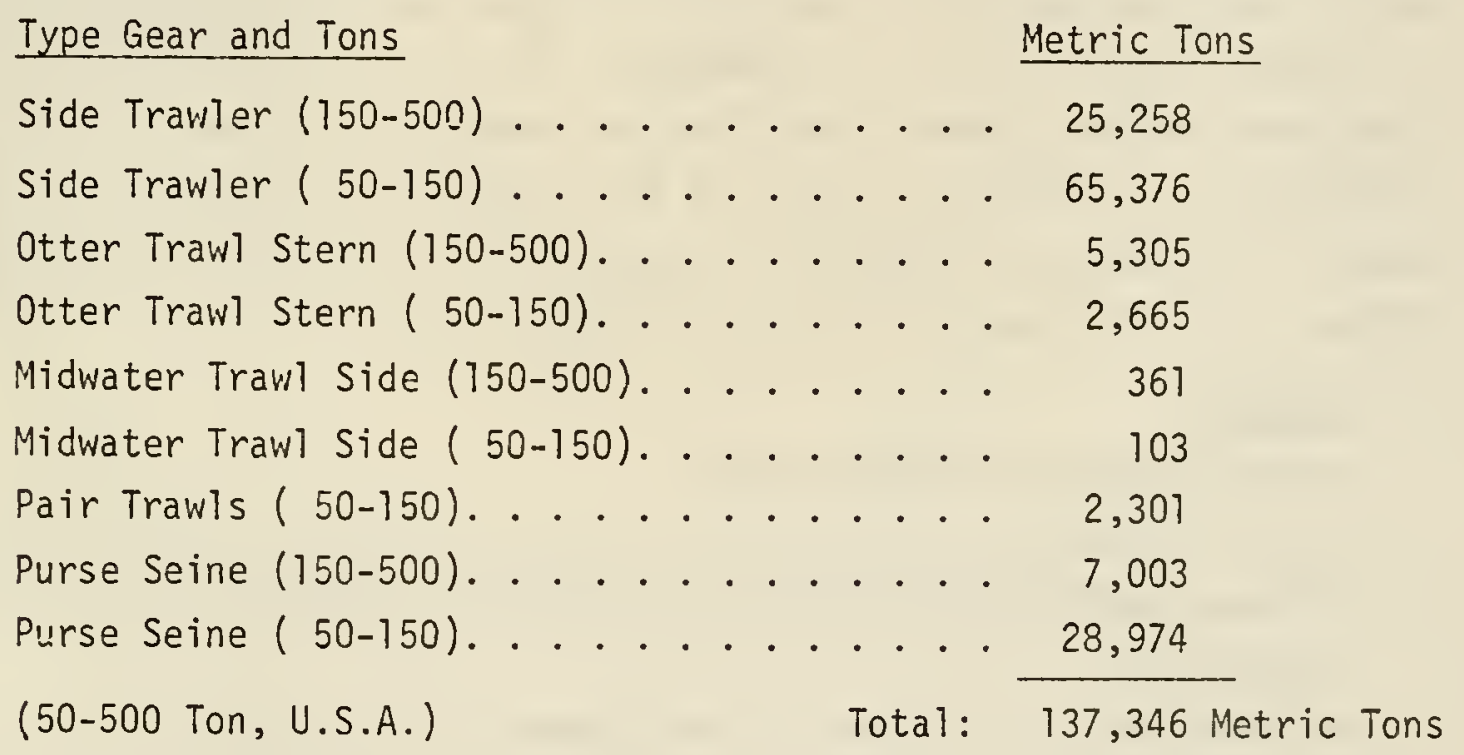

It may be of interest to note that the total 1973 Basic Catch of the U.S.A. in ICNAF Sub Areas 4, 5, and 6 is substantially less than the Total Allowable Catches as established by Allocation for 1976 in the same ICNAF Sub Areas. 
The existing offshore fleet of fishing vessels in the Northeast Fisheries that we are interested in analyzing consists of vessels classified as otter trawlers, and subclassified as large, medium, and small. The Tonnage Class is broken down into large, 150-499.9 tons; medium, 50-149.9 tons; smal1, 0-49.9 tons. There is no U.S. vessel in the existing fleet meeting the specifications of the proposed stern trawler mode. For analysis of the 600 ton model, the operational characteristics of the established classification, large 150-499.9 tons, will be utilized to develop the approximate size of the Target Fleet and economic feasibility. The operational characteristics refer to the range of catch in pounds associated with the trips of the existing large otter trawler class working offshore fishing grounds.

The majority of the established information regarding landings of catch from this operating area refer to the existing vessels, "01d Colony", "Tremont", and "Massachusetts", classifeid as large otter trawlers. Over a period of years, statistics generated by the National Marine Fisheries Service have indicated that landings for these vessels per trip range from approximately 60,000 1bs to 110,000 lbs. The Financial Assistance Section of National Marine Fisheries Services has supplied a figure of approximately $2,400,000$ ibs. (1090 metric tons) as an average yearly landing for the "01d Colony". The range in pounds per vessel per year can also be estimated as follows using the range of landings as established:

\section{Factors}

Average number of days per trip. . . . . . . . . . . 10

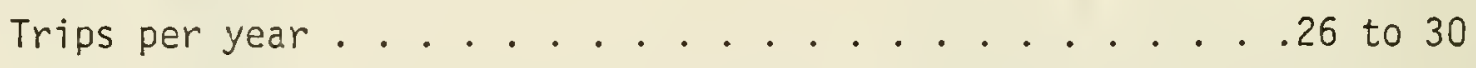

Minimum landings per year can be estimated at $60,000 /$ trip $\times 28$ trips $=$ $1,680,000 \frac{\pi}{\pi}$

Maximum landings per year can be assumed at 110,000\#/trip $\times 30$ trips $=$ $3,300,000 \#$

Approximate Average yearly landings $=2,490,000 \# /$ year or $(1132$ metric tons/year)

It can be noted that averaging the data on landings per vessel results in a figure closely approximating the value supplied by the National Marine Fisheries Service for the "01d Colony" 2,400,000\#/year (1090 metric tons/year). 
The historical data of 1973 United States Basic Catch in ICNAF Sub Areas 4, 5, and 6, which totaled 137,346 Metric Tons, can be used as an indication of the minimum number of vessels that may be required. Using the figure of 2,400,000 1bs/year/vessel or $1090 \mathrm{metric}$ tons/year/vesse 1 developed above as a criteria, approximately 126 vessels of this type are required.

Using the 1976 United States National Allocation, agreed to at the 1975 Annual Meeting of ICNAF, of 289,190 metric tons, approximately $\underline{265}$ vessels are required comparable to the class and current catch operating features of the "01d Colony" or "Tremont" class. The 1976 U.S. National Allocation for all finfish in subareas 5 and 6 is listed at 230,000 Metric Tons. To 1 and 230,000 Metric tons of finfish from these areas, approximately 211 vessels are required with a yearly landed rate averaging $2,400,000$ lbs per vessel (1090 metric tons per vessel). The size of the Target Fleet can therefore be estimated as ranging from approximately 126 vessels to 265 vessels. To assess the economic feasibility of the concept we suggest that a figure of 125 vessels be considered as the basic size of the Target Fleet. 
The question of technical feasibility is perhaps the easiest to answer, since the Boston Naval Shipyard has historically built, repaired, and maintained vessels much larger than those under consideration here. It is perhaps more germane to consider briefly the type of facility that would be needed and, based on the existing facilities, how much is needed in the way of new buildings and equipment. Again, it is important to stress that existing facilities must be viewed only in terms of their historical acquisition cost. Such costs would be horrendous and could not be justified by this concept, but they need not be considered at this time since the facilities are there and thus the "no-build" option is no option at all.

All of the operative and available docks at both the Charlestown and South Boston Naval Annex are large enough for fishing boat construction. (The \#1 dock at Charlestown is part of the U.S.S. Constitution Historical Park and thus assumed not available). As far as is known at this time, all of the docks are operable or could be made so with minimal remedial maintenance. There are many buildings, especially at South Boston, that could be utilized to build large sections of the boats or even the full hulls, so the notorious Boston Harbor weather need not be a productivity-reducing factor as it would be with large vessels. For those docks with cranes, the capacity and reach of the cranes appears more than adequate for servicing construction, repair, or maintenance of this class of vessels, though none of the cranes could alone or in combination be used for lifting completed vessels either for launch or retrieval.

It is not known at this point how much of the existing equipment at the yards has been left intact and in place by the Navy, but essentially all of the heavy equipment needs of such a yard (plate, rails, presses, shaft lathes, etc.) may be met by current facilities. Smaller equipment such as welding machines and other hand tools will almost surely have been removed by the Navy, so these will require new investment, and could well constitute the largest part of the new investment required. The very expensive automation equipment that most new shipyards instal1, flat panel lines for instance, would not be needed in this case, since the form and size of the vessels would not be conducive to a very capital 
intensive automated yard. Rather, manual assist machines which reduce setup time and the demands of the work force for sophisticated judgement and thus increasing the slope of the learning curve would be indicated. Semiautomatic frame benders and tape controlled plate cutting machines are perhaps the most obvious in this category. For launching completed vessels, there are several options open for use of the existing dry docks. Because of the time involved and the interruption of work on several vessels to launch one, and the problem of access and equipment to the bottom of the dock, several vessels may be launched at one time. If this type of launching operation proves to be less desirable after detailed study of the facilities, the docks can be used simply as very well protected slips and the boats can be launched and retrieved by either a Synchrolift or, a very simple and rudimentary floating dock. The smaller dry dock, which would be part of the maintenance and repair yard, of course, would be operated in the usual manner.

Finaliy, it must be stressed that the yard will have to have a substantial series of identical or nearly identical vessels if it is to take full advantage of the learning curve and economics of scale. 


\section{THE VESSEL DESIGN}

There is a very limited body of literature available on existing fishing vessel designs and almost none that look at the design process in the same orderly fashion as most other larger vessels are designed. Furthermore, although there are design rules for fishing vessels pub1 ished by Lloyd's Register of Shipping, these are old and in need of update. Literature generally indicates that rigorous design procedures based on classification society rules and standard naval architectural procedures are the exception rather than the rule. It appears that most fishing vessels are designed simply as modifications of existing vessels with most features based on the owner's preferences from experience rather than on standard practices. Likewise, the steel acutally used in the construction may well be more a function of what the boatyard happens to have on hand than the acutal scantlings called for in the plans.

There have, however, been some previous attempts to actually design a class of vessels that is specifically intended for the Boston groundfish industry. These studies have used varying techniques for design optimization, but even the best of them leaves much to be desired in their approach to the design process, the construction process, and the economics of operation. Given the limited nature and scope of this investigation, however, we have chosen to use one of the designs proposed as an optimum as the basis for our evaluation. This design was develoepd by Mr. Cyrus Haml in of Ocean Research Corporation in his study for the National Marine Fisheries Service entitled "An Optimum Trawler for Groundfish: Design Study" (January, 1971; NTIS "COM-72-11 298). While we are not prepared at this time to accept his design as a true optimum or near-optimum, it does seem to be a reasonable starting point until such time as a more detailed study can be conducted with the Boston Navy Yard facilities specifically in mind.

The ORC vessel is a stern trawler rather than a side trawler, a development that appears to be widely accepted as being operationally more efficient while having only a minimal effect on construction costs if any. Its principal characteristics are: 


$$
\begin{aligned}
\text { LOA } & =125.2 \mathrm{ft.} & \text { LBP } & =116.0 \mathrm{ft} . \\
D & =16.0 \mathrm{ft.} & T & =12.5 \mathrm{feet} \\
C P & =0.608 & C_{B} & =0.507 \\
H P & =1030 & \text { F.0. Cap. } & =51 \text { tons } \\
B & =28.7 \mathrm{ft.} & V & =12.5 \mathrm{ft} . \\
\Delta & =593 \text { tons } & F W & =7.4 \text { tons } \\
\text { Hard } & \text { Volume }=12,000 \mathrm{ft}^{3} & \text { Crew } & =16
\end{aligned}
$$

Crew size appears out of line with the current operating desires of fishing captains but has been noted as part of the ORC Study. A crew size of eight to twelve, dependent on gear arrangement and safety requirements, may be a more desirable complement. 


\section{VESSEL COSTS}

Whenever one is estimating vessel costs, it is important to make the distinction between cost and price. Cost is a measure of the resources that must be utilized to produce a vessel while price is more a measure of the current supply/demand balance or imbalance in the market for new or used vessels. The former is relatively stable and grows at a relatively stable rate in consent with general economic indicators such as inflation or GNP growth.

The latter, on the other hand, can show substantial variations over relatively short periods of time as the supply/demand picture varies. The market for fishing vessels is of course thin and inelastic, while the market for the resources to build fishing vessels is quite broad and elastic.

Generally, one has two procedural options to estimate vessel costs: the synthetical or the analytical. The synthetical simply designs and builds a vessel on paper and keeps track of the resources used in each step to arrive at a total cost. It can be a very useful and accurate approach, but it does require fairly detailed knowledge of the design of the vessel, the facilities that will be used to build it, and the specific methods of construction. The analytical approach requires the collection and the analysis of data concerning a range of other similar vessels and the presentation of such data as functional relationships or as graphs relating resource requirements to the vessel characteristics.

In the present case, our lack of full knowledge of the vessel, yard, or production specifics requires that the analytical approach be used. Although the literature abounds with analytical studies of larger ships of nearly every type, there is relatively little in the specific area of fishing vessels. Of the studies that were found, the most comprehensive was a paper by Benford and Kassa, "An Analysis of U.S. Fishing Boats Dimensions, Weights, and Costs". This paper appeared in "Fishing Boats of the World" issued by FAD in 1967. In principle, its findings on dimensions and weights would be applicable today as should the findings on unit labor productivities. The unit costs, of course, have undergone substantial inflation since 1967. For our cost estimate, we have used the Benford and Kassa estimates in weights and productivities as applied 
to the ORC vessel but have escalated materials and labor costs to present levels via the appropriate U.S: Department of Labor and Labor Statistics indices for the appropriate categories of wholesale goods and labor total compensation rates. We have used overhead rates of $70 \%$ on direct labor and $10 \%$ on materials and have added a yard profit of $10 \%$. Using this method, we arrive at a vessel cost of $\$ 704,500$, which, with a generous allowance for full year outfit, we will take at roughiy $\$ 750,000$ per vessel for individual or short series production. For long series production of the type envisiored here, Benford and Kassa estimate a unit cost $80 \%$ of the individual cost. We will be more conservative and say $85 \%$ for a series unit cost of about $\$ 640,000$. 
OPTIMUM VESSEL

(ORC-HAMLIN)

$$
\begin{array}{rlrlrl}
\text { LOA } & =125.2 \mathrm{ft} . & \text { LBP } & =116.0 \mathrm{ft} . & B & =28.7 \mathrm{ft} . \\
D & =16.0 \mathrm{ft} . & T & =12.5 \mathrm{ft} . & \Delta & =593 \mathrm{~T} \\
C P & =0.608 & C_{B} & =0.507 & V & =12.5 \mathrm{kt} \\
H P & =1030 & \text { F.O } & =50.6 \mathrm{~T} & \mathrm{FW} & =7.4 \text { tons } \\
\text { Hold } & =11990 \mathrm{ft}^{3} & \text { Crew } & =16 . & & \text { Accommodations }=19
\end{array}
$$

\section{TABLE I I}

WEIGHTS (Bonford and Kossa)

$$
C N=\frac{B L P * B * D}{100}=\frac{116 \times 28.7 \times 16}{100}=533
$$

From Figure 283

$$
\begin{aligned}
& c_{s} \approx .356 \\
& \therefore w_{\text {hull }}=c_{S} * C N- \\
& =190 \text { tons }
\end{aligned}
$$

Deckhouse Weight $\approx .015 * \mathrm{CN}$

$$
W_{D H}=8 \text { tons }
$$

Outfit and HuT1 Eng

From Figure 289

$$
\begin{aligned}
& c_{S} \approx .220 \\
& . W_{H E}=107 \text { tons }
\end{aligned}
$$

Machine Wt. from Figure 285

$$
W \text { mach }=35 \text { tons }
$$

Auxiliary Mach from Figure 286

$$
\begin{aligned}
& c_{\mathrm{s}} \approx .06 \mathrm{cn} \\
& w_{\text {aux }}=32 \text { tons }
\end{aligned}
$$




\section{$\underline{T A B L E ~ I I I}$}

VESSEL COST (INDIVIDUAL OR SHORT SERIES)

CATEGORY

Hull

Deckhouse

$O$ and $H E$

Mach

Aux Mach

Subtotals

overhead

Subtotals

Profit o $10 \%$
WEIGHT

190 tons

8

107

35

32

372 tons

MATERIALS COST MH/T

MH

LABOR COST

TOTAL COST

(c) $31.5 \$ 60,000 \quad 100$

$19,000 @ \$ 4.50 \$ 85,500$

$\$ 145,500$

$2,50 \div \quad 130 \quad 1,040$

4,700

7,200

(c) $490 \quad 52,500 \quad 180 \quad 19,260$

86,700

139,200

(82221 $71,100 \quad 180$

256,100

(210\% 25,600

281,700

$$
1,750
$$

7,900

77,900

$\underline{5,760}$

$46,810 \mathrm{MH}$

$\frac{25,900}{210,700}$
$\frac{147,500}{358,200}$

639,900

$\frac{64,000}{\$ 704,000}$ 
To translate the cost of each vessel into a regional lease rate, the rate the owners of the vessel must charge the crew and captain in order to recoup their investment, will require a number of assumptions. For simplicity, we will assume a zero debt.-equity ratio and analyze the owner's position from a simple cash flow point of view. The actual situation might be quite different depending on the owning entity's particular capital and tax position and on such factors as the possible use of $\mathrm{Ma}-$ terial Marine Fisheries Service loan guarantees to obtain part of the capital at low guaranteed rates. For this degree of analysis, however, the cash flow alone will suffice. We will also assume a range of internal discount factors for the owners and will assume that the owner can use the investment tax credit. Beyond that, we will assume only that the owner will require a lease rate at least sufficient to cover his direct expenditures plus a fifteen year amortization of his investment at the appropriate discount rate.

Vessel expenses have been estimated based on "Costs and Earnings of Selected Fishing Enterprises in Nova Scotia in 1973", published by the Department of Fisheries, Province of Nova Scotia, in February, 1975. The only costs to the owners account are maintenance and repair, estimated at $\$ 10,000$ per year, plus $\$ 60,000$ per year insurance cost. Thus, the minimum annual lease rate acceptable to the owners would be approximately $\$ 137,000$ at $8 \%$ discount rate, $\$ 746,000$ at $10 \%, \$ 155,000$ at $12 \%$ or $\$ 164,000$ at $14 \%$. On a daily basis, these lease rates work out (based on 250 lease days per year) at $\$ 549, \$ 583, \$ 618$, and $\$ 655$ at the four discount rates respectively. It must be pointed out, of course, that the day rates are annual averages and any short term or single voyage leases would be subject to a premium and to seasonal variations.

Of interest at this juncture is the ability of offshore fishing entities to lease this vessel at the rates indicated. In order to establish this ability, some indication of the amount of general gross revenues is required in addition to operating costs and revenue sharing. To establish gross revenues for the large offshore Otter Trawler statistics will be used for the period January, 1975, to July, 1975, in addition to establishment of ex-vessel prices for fish landed in preceeding years. 


\section{DISCOUNT FACTORS}

$\begin{array}{rrrrrr}\text { Year } & \underline{8 \%} & \underline{10 \%} & \underline{12 \%} & \underline{14 \%} \\ 1 & .926 & .909 & .893 & .877 \\ 2 & .857 & .826 & .797 & .769 \\ 3 & .794 & .751 & .712 & .675 & 1 \\ 4 & .735 & .683 & .636 & .592 & (1+i)^{n} \\ 5 & .681 & .621 & .567 & .519 \\ 6 & .630 & .564 & .507 & .456 \\ 7 & .583 & .513 & .452 & .400 \\ 8 & .540 & .467 & .404 & .351 \\ 9 & .500 & .424 & .361 & .308 \\ 10 & .463 & .386 & .322 & .270 \\ 11 & .429 & .350 & .287 & .237 \\ 12 & .397 & .319 & .257 & .208 \\ 13 & .368 & .290 & .229 & .182 \\ 14 & .340 & .263 & .205 & .160 \\ 15 & .315 & .239 & .183 & .140 \\ \Sigma & 8.559 & 7.606 & 6.811 & 6.142\end{array}$

$$
\begin{array}{rlrl} 
& \begin{array}{c}
\text { M\&R\& } \\
\text { Insurance }
\end{array} & \begin{array}{c}
\text { Daily Rate } \\
250 \text { days }
\end{array} \\
\text { Annuat Bareboat Rate o } 8 \%=\frac{640,000 \times .9}{8.559} \approx \$ 67,000 \quad \$ 70,000 & \approx 549 \\
10 \%= & \approx 76,000 \quad 70,000 & \approx 583 \\
12 \%= & \approx 85,000 \quad 70,000 & \approx 618 \\
14 \% & \approx=94,000 \quad 70,000 & \approx 655
\end{array}
$$




\section{EXIST ING LARGE OFFSHORE OTTER TRAWLER YEARLY GROSS REVENUES}

Several Discreet inquiries have been made to both the Financial Assistance Vessel Subsidy Section of the National Marine Fisheries Service and the Industry in attempts to get actual yearly gross revenue figures for the large offshore otter trawler. The National Marine Fisheries Service is particularly sensitive to requests for this type of information, stating that such information cannot be disclosed. This applies to all vessels in the Vessel Subsidy Program even though requests do not apply to current year operations. The Service, nevertheless, did supply a figure of approximately 2,400,000 lbs as the yearly average landing for the "01d Colony" operating from the Boston Fish Pier. Exact figures of yearly gross revenues of particular vessels operating in the U.S. Northeast Fisheries are not required for this preliminary assessment of the South Boston Naval Annex Concept since the representative fleet is made up of a conglomeration of vessels. The range of yearly gross revenue can readily be developed from Fishery Market News Reports of landings and ex-vessel prices for first sales. Utilizing this type of data may give a more representative sample of gross revenues than can be expected from vessel operations ranging from efficient to marginal.

For the period of January, 1975 to July, 1975, landings and prices paid were averaged for the classification, Large Otter Trawler, operating out of the Boston Fish Pier. A figure of $\$ 3240$ per CWT was developed for the vessels operating from the Boston Fish Pier for this period.

Eliminating a number of unusually high ex-vessel species price days in the Boston figures resulted in reduction of the figure to an average of $\$ 3090$ per CWT.

To establish a relationship of the operation of New Bedford trawlers to the Boston Fish pier, the same period of January, 1975 to July, 1975 was analyzed. An average of $\$ 3132$ per CWT was developed for the New Bedford effort. Elimination of the same days that were cut from the Boston figures resulted in an average of $\$ 2993$ per CWT.

For the preliminary economic assessment of the operation of the model 600 ton vessel, a yearly landing of 2,400,000 lbs at an average 1975 price of $\$ 0.30-\$ 0.31 / 1 \mathrm{~b}$. can be used. 
APPROXIMATE AVERAGE PRICE OF SPECIES LANDED

January 6, 1975 - JuTy 17, 1975

BOSTON

Date (Day) Number of Gross \$/ Height

Average \$

Vessels in thousands of 1 bs.

Percent

$7 / 17$, Thurs.

1

$\cdot 2$

$7 / 10$, Thurs.

6/27, Fri.

2

$6 / 12$, Thurs.

1

2

$6 / 10$, Thes.

$5 / 20$, Tues.

$5 / 15$, Thurs.

$5 / 13$, Thurs.

$5 / 14$, Wed.

$5 / 6$, Tues,

5/ 5, Mon.

$.5 / 1$, Thurs .

$4 / 28$, Mon.

4/21, Mon.

4/11, Fri.

4/ 1, Tues.

$3 / 18$, Tues .

3/12, Wed.

3/ 4, Tues.

$2 / 27$, Thurs.
$\$ 144,000 / 41.4$

. $232,230 / 59.4$.

$249,015 / 100.6$

$206,720 / 64.5$

$249,795 / 106.6$

$219,360 / 106.8$

$107,060 / 41.8$

$272,305 / 90.8$

$172,930 / 57.4$

$158,930 / 59.6$

$188,075 / 87.4$

$192,500 / 70.8$

$402,210 / 125.3$

$441,340 / 141.0$

$207,349 / 63.5$

$358,190 / 78.0$

$286,810 / 66.3$

$377,650 / 100.6$

$387,200 / 116.0$

$441,220 / 122.5$

$320,250 / 106.8$
$\$ 3,478$

3,909

2,475

3,205

2,343

2.,054

2,561

3,032

3,013

2,667

2,152

2,719

3,210

3,130

3,265

4,592 *ᄎ

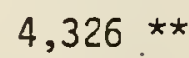

3,754

3,338

3,602

2,999 
APPROXIMATE AVERAGE PRICE OF SPECIES LANDED

January 6, 1975 - July 17, 1975

\section{BOSTON}

Date (Day)

Number of - Gross \$/Height

Vessels in thousands of lbs.

Average \$

Percent

$2 / 19$, Wed.

$2 / 12$, Wed.

$2 / 6$, Thurs.

$1 / 30$, Thurs.

$1 / 20$, Mon.

$1 / 9$, Thurs .

$1 / 6$, Mon

Total Average
1

1

1

1

2

1

1
$\$ 442,910 / 113.1$

$298,700 / 72.3$

$324,480 / 113.6$

$311,750 / 115.3$

$436,300 / 145.0$

$169,025 / 45: 2$.

$227,220 / 50.1$
$\$ 3,916$

4,131

2,856

2,704

3,009

3,739

$4,535 \star \star$

$\$ 90,714 / 28$ Sample

$\$ 3240$ per day per CWT.

(32 Cents per pound)

** $\$ 77,261 / 25$ Sample

$\$ 3090$ per day per CWT

( 31 cents per pound)

$\star \star$ Excluded 


\section{NEW BEDFORD}

Date (Day)

Number of Vessels
Gross \$/Weight in thousands of $7 \mathrm{bs}$.
Average $\$$

Percent

7/17, Thurs.

9

$\$ 840,650 / 253.1$

$\$ 3,321$

$7 / 10$, Thürs .

6

$807,868 / 238.4$

3,389

6/27, Fri.

9

$594,700 / 271.6$

2,190

$6 / 12$, Thurs.

8

$706,959 / 270.7$

2,612

6/10, Tues.

$632,352 / 164.2$

3,851

5/20, Tues.

$523,512 / 291.2$

1,798

5/15, Thurs.

$390,492 / 212.5$

1,838

$5 / 13$, Tues.

5

$270,197 / 117.9$

2,292

$5 / 14$, Wed.

$.423,736 / 229.5$

1,846

5/ 6, Tues.

10

$833,222 / 363.3$

2,293

5/ 5, Mon.

9

$710,374 / 298.4$

2,380

$965,724 / 412.9$

2,311

2,644

4/28, Mon.

13

$1,220,749 / 461.7$

NO INFORMATION

4.21, Mon.

$-$

12

$691,550 / 427.3$

1,618

4/11, Fri.

6

$508,907 / 90.6$

5,617

4/ 1, Tues.

4

$310,942 / 70.3$

$4,423 * *$

$3 / 18$, Tues .

4

$266,492 / 62.7$

$4,297 * *$

$3 / 12$, Wed.

6

$564,253 / 168.8$

3,343

3/ 4, Tues.

6

$292,859 / 73.2$

4,001

$2 / 27$, Thurs.

9

2,968 
APPROXIMATE AVERAGE PRICE OF SPECIES LANDED

\section{January 6, 1975 - Ju1y 17, 1975}

NEW BEDFORD

Date (Day)

Number of Gross \$/Height

Vessels in thousands of los.

Average \$

Percent

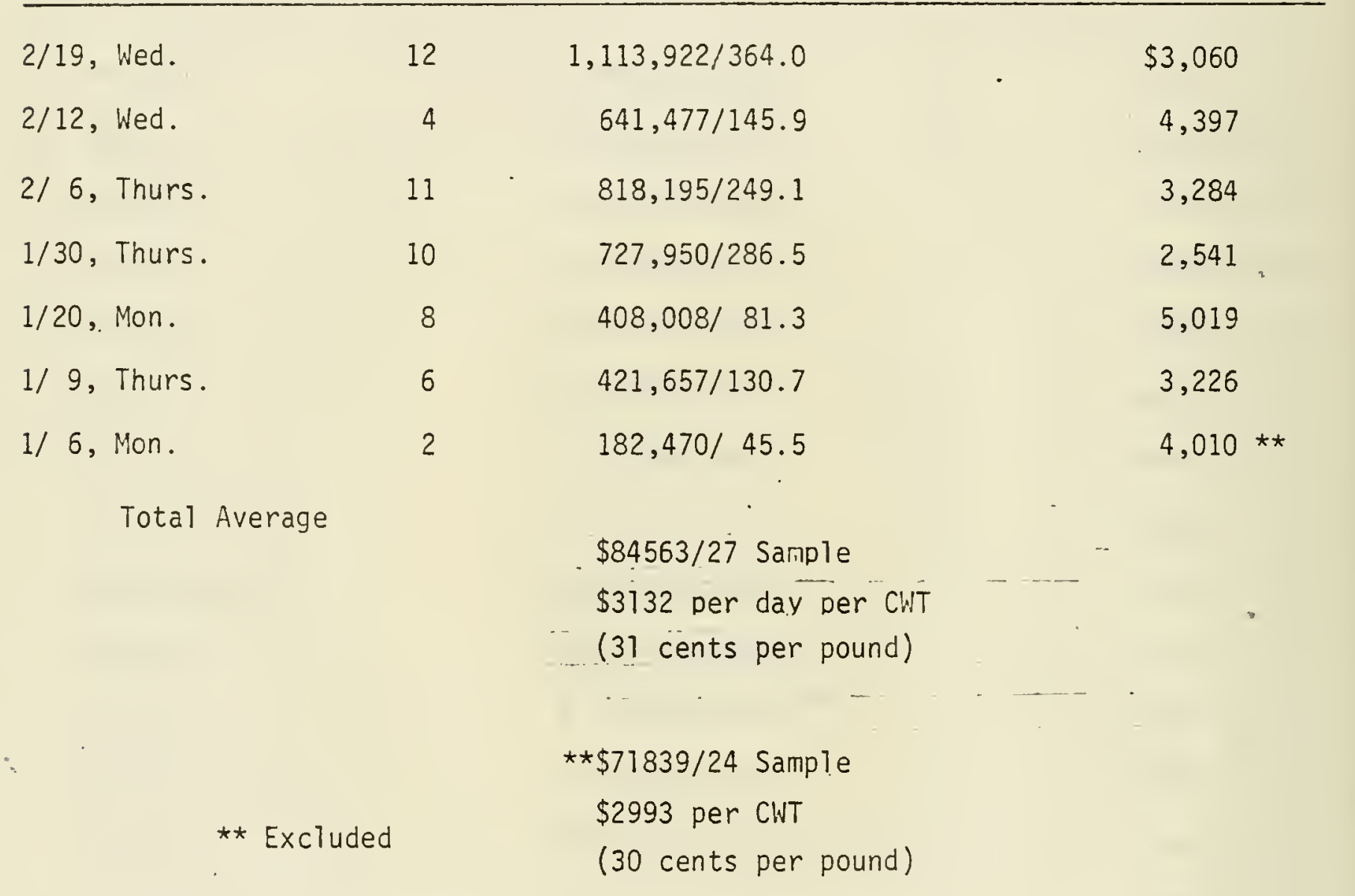


Massachusetts landings for various species associated with otter trawls for the years 1970 and 1971 are also included. The average price per pound for species associated with the offshore industry for this period is approximately $\$ 0.14 / 1$ b. Adjustment for inflation from this period to 1975 indicates that the average price of $\$ 0.30$ to $\$ 0.32 / 1 \mathrm{~b}$. developed for Boston and New Bedford using landing statistics for the period January 1975 to July 1975 are reasonable assumptions. 
1970

MASSACHUSETTS LANDINGS OF CATCH

(OTTER TRAWL ONLY)

Species

Pounds

Dollars

cod

$35,279,300$

$\$ 4,053,355$

Cusk

675,500

53,019

Flounders

Blackback

$15,673,200$

$2,343,927$

Dab

$4,330,600$

637,776

Fluke

37,100

14,011

Grey Sole

$4,625,900$

748,873

Lemon Sole

$1,942,000$

493,644

Yellowtail

$57,392,000$

$8,647,914$

Haddock

$23,517,500$

$5,317,936$

Hake

Red

465,500

19,933

White

$2,175,300$

148,630

76,500

41,892

$7,896,300$

418,748

$7,119,200$

536,809

370,700

140,229

Whiting

$20,616,400$

$1,790,359$

Wolfish

532,600

30,870

Scallops, sea

37,600

50,903

subtotal

$182,764,700$ \#

$25,538,828$

Average Price/7b. $\$ 0.14$

(Including Following Species for 1970:)

Herring, Sea

$16,001,900 \#$

275,407

Mackere], Atlantic

645,800

36,514

Unciassified Food Fish

$4,451,700$

487,823

Squid

332,900

34,583

Subtotal

$21,432,300 \#$

834,327

Tota 1

204,197,000\#

1970 Average Price/Pound \$0.13 
MASSACHUSETTS LANDINGS $\underline{\underline{1971}}$

(OTTER TRAWLS ONLY)

Species

Pounds

1971 Dollars

Cod

$37,454,900$

$\$ 4,760,716$

Cusk

651,200

67,440

Flounders

B 7ackback

$14,326,400$

$2,322,896$

Dab

$4,204,100$

625,010

Fluke

60,000

33,417

Grey Sole

$5,521,300$

933,131

Lemon Sole

$2,629,400$

699,880

Yellowtail

$41,848,100$

$6,874,538$

Haddock

$18,961,300$

$4,916,636$

Hake

Red

805,100

40,490

White

$3,138,700$

202,176

73,500

44,347

$13,337,000$

699,843

$8,991,500$

713,658

366,300

133,828

$15,074,900$

888,007

564,200

39,152

Wolfish

47,400

62,640

Scallops, Sea

Subtotal:

$168,707,200 \#$

$\$ 24,057,805$

1971 Average Price/Pourd: $\$ 0.14$

(Including Following Species for 1971:)

Herring, Sea

$30,642,800$

210,500

Mackerel, Atlantic

661,900

Squid

Unclassified Food Fish

Subtota 7 :

Total:

$$
\begin{aligned}
& \frac{4,636,200}{36,151,400 \#} \\
& +\quad \frac{168,707,200}{\$ 204,858,600} \\
& \$ 0.12
\end{aligned}
$$

$\$ 524,680$

8,952

46,655

$\frac{531,100}{\$ 1,111,387}$

$+\quad 24,057,805$

$\$ 25,169,192$

1971 Average Price/Pound: $\$ 0.12$ 
The question of crew net income potential, the measure of the attractiveness of the leased boat concept to potential fishing crews is a relatively complex one due, in no small part, to the lay system which is the traditional system of sharing gross revenues and expenses of a given voyage among the crew, other officers, and the vessel owners. Certainly, the concept being discussed here presents the possibility of the crew acting cooperatively to lease a boat, but this would involve a capital risk to the crew members, which may not be of interest to them. Even under the lay system, the crew takes the risk of a bad voyage, but their risk is limited to their time only, and involves no monetary investment. Because of the long tradition of the lay system and the reported failure of previous attempts to change it, we will assume for this preliminary analysis that the lay system will survive in some form.

This will reqire that an intermediary, perhaps the captain, lease the boat and then assemble a crew to operate it. This intermediary will require a share of the gross revenues sufficient to cover the lease payment plus a return on his investment in the lease. If the captain is the intermediary, he will, of course, also require compensation for his personal services. It is further likely that the amount of his share will be based on the traditional lay system.

It should be noted that the lay system complexity lies in the fact that each fishing port and different fishing entities in the same port use different variations of lay systems. The offshore fleet appears to operate on variations of the Boston lay system, which basically divides net revenues between ship share and crew share at a rate of 40 and 60 percent respectively. This format will be utilized to establish a ProForma Settiement Sheet.

To check whether the lay system will provide sufficient wages to the crew and captain and return to the intermediary, we can construct a ProForma settlement sheet based on an assumed average voyage. The assumption is based on an annual catch rate of two million pounds, approximately 23 voyages per year, thus 87,000 pounds per voyage, and an average price of 32 cents per pound. The Pro Forma Settlement Sheet under these assumptions and using the lease terms based on a ten percent discount factor is shown in Table $V$. 
Pro-Forma Settlement Sheet

Based on 10\% Discount Factor

Gross Revenues . . . . . . . . . . $\$ 27,840$ Less:

Wharfage

Scales

Exchange Fee

Chief Engineer

Second Engineer

Mate

Miscellaneous

Net Revenues . . . . . . . . . \$27,016.00

Ship Share $(40 \%)$.... $\$ 10,806.40$

of which

Lease 11 days $583 \ldots . . \$ 6,413.00$.

Captain's Wages $050,000 /$ year . $\$ 2,174: 00$.

Profit....... \$2,219.40

Profit as \% of Lease . . . 55\%

Profit as \% of Lease plus

captain's wages..... 26\%

Crew Share $(60 \%) . . . \$ 16,209.60$

less:

Fuet .... \$2,000.00

Lube . . . . \$ 100.00

Provisions . . \$1,200.00

Miscellaneous $\frac{\$ 700.00}{4,000.00}$

Net Crew Share

$\$ 12,209.00$

*15 shares 0 \$814.00

Equivalent Annual wage @ 23 voyages $=\$ 18,720.00$

*12 man crew is considered possibte on this

class of vesse?. 


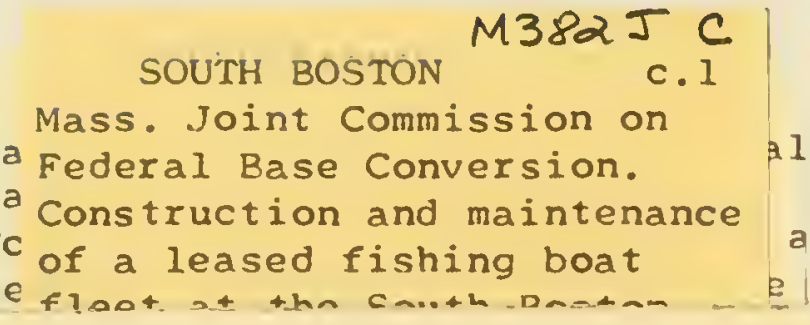

South Boston Naval Annex. 
$=$ 
